\title{
Editorial
}

\section{Assessing importance and value}

— fficiency, effectiveness, value for money, importance - these seem to be the mantras of the present age. They are applied to all areas of human activity, including science, yet finding scientifically robust and independent methods of assessing them is difficult. In science how can we show that one group is more effective than another, that the ideas of one individual are more important than those of others, that money invested in one type of research provides better value than in another? In industry the success of most research is measured in new products and profits. But for blue-skies research whose outputs are papers in the scientific literature, the ISI Citation Index and its various derivatives is still the principal quantitative method used. Its inadequacies for assessments have been detailed wrong names, linked groups, variable half lives for different subjects, over citation of review and method papers etc. Yet, such is the simplicity of the system, many still use the citation value to decide on the destination of their next submission or the value of previously published material.

Two recent articles in Nature (Impact takes precedence over interest, D. Schoonbaert \& G. Roelants 391, 222, 1998)) and TREE (What do impact factors tell us? H. Kooko \& W.J. Sutherland, 14, 382384,1999 ) have again questioned the use of citation indices. Assessment committees - be they for grants or promotion - often demand to see citation tables for individuals and groups. Funding agencies still clutch onto the ISI rankings of journals to help in comparing different groups for funding decisions. But the article in TREE shows quite clearly that any attempt to compare indices for different disciplines is both scientifically and logically indefensible. Even comparisons within disciplines have to be carefully constrained if they are to be of any use. To test this against user perceptions I conducted a small trial on journal importance myself. I provided five leading British scientists in different fields of terrestrial biology with a list of around 50 journals with citation indices from 20 to 0.1 and asked them to rate the importance of the journals on a five-point scale. None listed either Science or Nature at the top and all clearly showed their sub-disciplinary biases. Interestingly, interdisciplinary journals were clearly not seen to be as important as disciplinary journals.

If comparing numerical citation ratings between disciplines is scientifically unsound then it follows that this should not be used in decision-making. If interdisciplinary journals are generally judged less important than disciplinary ones it follows that the papers they attract will also be less important and the feedback loop should result in their citation values being lower. If these numerical continue to be used as indicators of importance and value the narrow view will benefit at the expense of the broad, the rapid research at the expense of the long-term. How then are we to achieve the holistic approach, the interdisciplinary breakthrough so beloved of the speeches of our leaders? Perhaps common sense and intelligence will save us!

Journals like Antarctic Science cannot claim high citation indices. They exist for those who want to interest those outside their field, as well as those inside, in their science. Regretfully, we cannot discount the prejudicial use of citation indices that will continue to underpin poor decisions and motivate choices. We can, however, try to ensure that for at least some of the time those who want to reach a wider audience than their most specialised colleagues have somewhere to go. Meanwhile we should all continue to look for better ways of measuring importance, effectiveness and value for money.

DAVID W.H. WALTON 
The editors and Antarctic Science wish to thank the following specialists who have assisted them by providing referees' reports and advice on papers received throughout the year.

$\begin{array}{llll}\text { I.-Y. Ahn } & \text { J.A.E. Gibson } & \text { R. Leakey } & \text { J. Sargent } \\ \text { L. Allcock } & \text { D. Gillieson } & \text { A. Leventer } & \text { A.D. Saunders } \\ \text { M.E. Anderson } & \text { J.M. Godoy } & \text { B. McConnell } & \text { C. Saunders } \\ \text { P.S. Anderson } & \text { D.B. Gore } & \text { C. McKay } & \text { R.P. Scherer } \\ \text { A. Ansell } & \text { K. Green } & \text { D.M. McKnight } & \text { C.J. Secombes } \\ \text { J. Arnauld } & \text { D.H. Griffiths } & \text { J. Montgomery } & \text { P.D. Shaughnessy } \\ \text { R.A. Bamber } & \text { C. Guinet } & \text { E. Murphy } & \text { D. Sheppard } \\ \text { D.J. Batten } & \text { S. Gunther } & \text { B. Moss } & \text { D. Siniff } \\ \text { M.J. Bentley } & \text { S. Harley } & \text { J. Mutterlose } & \text { I.P. Skilling } \\ \text { R. Bintanja } & \text { J. Harwood } & \text { D. S. Nichols } & \text { J. Smellie } \\ \text { P. Bouchet } & \text { P.J. Hayward } & \text { A.W. North } & \text { V. Smetacek } \\ \text { I.L. Boyd } & \text { E. Hejl } & \text { J. O'Neill } & \text { R.H. Spigel } \\ \text { T. Brey } & \text { G. Herndl } & \text { H.W. Palm } & \text { B. Storey } \\ \text { D.H. Bromwich } & \text { M.A. Hindell } & \text { J.R. Pawlik } & \text { E. Stump } \\ \text { D.E. Cartwright } & \text { E. Hofmann } & \text { L.S. Peck } & \text { C.W. Sullivan } \\ \text { R. Cattaneo-Vietti } & \text { C. Howard-Williams } & \text { M. Philippe } & \text { F. Tessensohn } \\ \text { C.A. Child } & \text { G.L. Hunt, Jr } & \text { A.M. Pires } & \text { M. Thorndike } \\ \text { A. Clarke } & \text { S.S. Jacobs } & \text { G.C.B. Poore } & \text { C. Todd } \\ \text { A.P.R. Cooper } & \text { H.A. Jonkers } & \text { C. Le Provost } & \text { S. Vanfone } \\ \text { J. Davenport } & \text { A.B. Josefson } & \text { I. Raine } & \text { P. Virtue } \\ \text { J.T. Eastman } & \text { P.A. Jumars } & \text { A. Reading } & \text { H. Wagele } \\ \text { M. Fedak } & \text { M.C. Kennicutt II } & \text { J. Reavy } & \text { M. Wedborg } \\ \text { W.H. Fenical } & \text { J. King } & \text { P.M. Rees } & \text { R.A. Wharton } \\ \text { G. Fryxell } & \text { N.T. Klages } & \text { T.R. Riley } & \text { N.E. Whitehead } \\ \text { M. Fukuchi } & \text { J. Kowalke } & \text { W. Ritzrau } & \text { R. Willan } \\ \text { R.W. Furness } & \text { T. Kubodera } & \text { P. Roos } & \text { W.J. Zinsmeister } \\ \text { J. Gamble } & \text { P.R. Kyle } & \text { G. Rowbotham } & \\ \text { R. Gersonde } & \text { B.E. Leake } & \text { N.J. Russell } & \\ & & & \end{array}$

The total number of manuscripts handled by the editorial office during 1999 was 107, of which 71 were new submissions. 50 papers were published this year. 